\title{
PRZEJAWY RECENTRALIZACJI NA PRZYKŁADZIE KONSTRUKCJI ZESPOLENIA POWIATOWYCH SŁUŻB, INSPEKCJI I STRAŻY
}

\section{Wprowadzenie}

Funkcjonowanie administracji publicznej wymaga odpowiednich rozwiązań prawnych kształtujących jej organizację. Z uwagi na to, że struktura administracji jest rozległa, konieczne staje się określenie relacji pomiędzy jej częściami składowym przy wykorzystaniu właściwych zasad. W celu umożliwienia prawidłowego wywiązywania się przez administrację publiczną z powierzonych jej zadań wyznaczone zostały pewne ogólne, podstawowe zasady, niektóre wspólne dla całej administracji (np. zasada praworządności), a inne odnoszące się do poszczególnych jej segmentów, w tym wyłącznie do administracji rządowej czy samorządowej (np. zasada resortowości, koncentracji, pomocniczości) ${ }^{1}$.

* Ewelina Dziuban - Katedra Prawa i Postępowania Administracyjnego oraz Nauki o Administracji, Krakowska Akademia im. Andrzeja Frycza Modrzewskiego w Krakowie, starszy asystent sędziego w Wojewódzkim Sądzie Administracyjnym w Krakowie.

${ }^{1}$ J. Jaskiernia, Zasady organizacji administracji rządowej [w:] Konstytucyjny system władz publicznych, red. P. Chmielnicki, Warszawa 2009, s. 132. 
Centralizacja i decentralizacja rozumiane jako ogólne pojęcia stosowane $\mathrm{w}$ procesie organizacji nazywane są technikami organizacji ${ }^{2}$. $\mathrm{Z}$ punktu widzenia nauki prawa administracyjnego postrzegane są one jako relatywne, przeciwstawne dyrektywy systemu prawa, określające układ stosunków między organami administracji publicznej. Są one immanentnie związane z procesem administrowania, rozumianym jako wykonywanie określonych prawem zadań państwa.

\section{Pojęcie centralizacji}

Centralizacją nazywa się taki sposób zorganizowania struktury administracji w układzie wertykalnym, w którym organy niższego stopnia są podporządkowane organom wyższego szczebla. Oznacza to pełne podporządkowanie o charakterze pionowym, przejawiające się podwójną zależnością - osobową i służbową. W układzie tym zależność służbowa sprowadza się do tego, że organ niżej usytuowany nie posiada prawnej samodzielności i niezależności. W praktyce oznacza to możliwość wydawania przez organ wyższego stopnia (usytuowany bezpośrednio wyżej w hierarchii lub w ogóle wyżej) poleceń służbowych, wytycznych i instrukcji organowi niższego szczebla. Natomiast zależność osobowa polega na prawie decydowania o obsadzie stanowisk ulokowanych bezpośrednio lub pośrednio niżej

W pewnym uproszczeniu, można stwierdzić, że układ scentralizowany polega na związaniu organów niższego stopnia dyrektywami organów nadrzędnych, na ingerencji w strefę działania organu niższego, w formie zarządzeń i poleceń służbowych, instrukcji wytycznych i innych aktów kierowania, czyli układ ten opiera się na więzach kierowniczych ${ }^{4}$.

2 Z. Leoński, Zarys prawa administracyjnego, Warszawa 2004, s. 55.

3 J. Szreniawski, Wstęp do nauki administracji, Lublin 2000, s. 62; J. Starościak, Prawo administracyjne, Warszawa 1996, s. 63; P. Tusiński, Zasady ustrojowego prawa administracyjnego [w:] Ustrojowe prawo administracyjne, red. L. Bielecki, P. Ruczkowski, Warszawa 2011, s. 69; S. Cieślak, Zasady organizowania administracji publicznej, Przemyśl 2014, s. 33.

4 S. Cieślak, Zasady..., s. 34. 
Omawiana zasada ma kluczowe znaczenie dla administracji rządowej, oddziałując na ukształtowanie jej struktury. Zgodnie z tą zasadą, w ramach struktury administracji rządowej mamy do czynienia $\mathrm{z}$ hierarchicznym podporządkowaniem organów niższego rzędu organom stojącym wyżej w strukturze, aż do organów naczelnych ${ }^{5}$.

Dążenia centralistyczne występują powszechnie w administracji współczesnych państw, w każdym z nich istnieją bowiem dziedziny działania i struktury administracji scentralizowanej, niezależnie od utrzymywanych tendencji do decentralizacji ${ }^{6}$. Przede wszystkim jednak nie można tracić z pola widzenia tego, że centralizacja stanowi również czynnik sprzyjający autorytarnej koncepcji rządów, prowadzi do wyobcowania wąskich kręgów decydentów z ich społecznego środowiska, jest barierą w procesach demokratyzacji, ogranicza inicjatywę i aktywność organów podporządkowanych, sprzyja zrutynizowaniu postaw urzędniczych i podporządkowaniu ich formalnym wymaganiom narzuconym z góry, zwiększa stopień ryzyka decyzji podejmowanych według dyrektyw formułowanych na wysokich szczeblach struktury.

\section{Ujęcie zasady zespolenia w doktrynie prawa administracyjnego}

W sensie legislacyjnym przez realizację zasady zespolenia rozumie się jej funkcjonowanie w ustawodawstwie po 1990 r. Przedmiot rozważań w tym zakresie należy poprzedzić zdefiniowaniem pojęcia zespolenia administracyjnego, przy użyciu którego począwszy od okresu międzywojennego po dzień dzisiejszy konstruuje się, ogólnie rzecz ujmując, podział pracy w administracji.

Pojęcie o tak długim rodowodzie, będące częścią języka prawnego i prawniczego, nie doczekało się legalnej definicji i przez to jego desygnat pozostaje dość enigmatyczny.

\footnotetext{
${ }^{5}$ J. Jaskiernia, Zasady... [w:] Konstytucyjny..., red. P. Chmielnicki, s. 133.

${ }^{6}$ J. Jeżewski, Centralizacja, decentralizacja [w:] Encyklopedia prawa, red. K. Kalina-Prasznic, Warszawa 2004, s. 68.
} 
Podejmując się próby ustalenia znaczenia tej konstrukcji prawnej, należy odwołać się do literatury przedmiotu ${ }^{7}$. W uproszczeniu przyjąć można, że zespolenie administracyjne jest pewną zasadą konstrukcyjną aparatu administracyjnego w terenie (występującą w administracji na szczeblu wojewódzkim i powiatowym), wyrażającą w swym modelowym, pełnym kształcie dążenie do skoncentrowania tego aparatu w maksymalnym stopniu w danej jednostce terytorialnej, w ramach jednego urzędu i pod jednym zwierzchnikiem, czyli do skupienia maksymalnie wielu zadań i kompetencji w jednym ośrodku władzy publicznej ${ }^{8}$. Konstrukcja zespolenia aparatu administracyjnego oznacza konsolidację różnych rodzajowo działów administracji przy monokratycznym organie administracji ogólnej z zakresem działań dostosowanym do zespalanych przez niego działów administracji, co jest przeciwieństwem zasady specjalizacji, czyli takiego sposobu organizacji struktury administracji, gdzie zakres działania dotyczy spraw o charakterze jednolitym i niezróżnicowanym ${ }^{9}$.

\section{Zasada zespolenia administracyjnego w ujęciu historycznym}

W celu kompleksowego ujęcia konstrukcji zespolenia nie można pominąć historycznego wymiaru tej zasady. Przypomnieć bowiem wypada, że pojęcie to, wykształcone w Polsce w okresie międzywojennym, zniknęło z języka prawnego i prawniczego na długie lata, żeby następnie zostać przywrócone $\mathrm{w}$ aktach prawnych związanych $\mathrm{z}$ reformą ustrojową z końca lat $90{ }^{10}$

7 Szerzej na ten temat E. Dziuban, Realizacja zasady zespolenia $w$ administracji rządowej w województwie, „Przegląd Prawa Publicznego” 2014/9.

8 A. Wiktorowska, Terenowe organy administracji państwowej [w:] System Prawa Administracyjnego, t. 6, Podmioty administrujace, red. R. Hauser, Z. Niewiadomski, A. Wróbel, Warszawa 2011, s. 384.

9 Cz. Baraniecki, J. Konicki, Konstrukcja zespolenia w polskiej administracji publicznej, „Ius et Administratio” 2006/10(2), s. 123.

${ }_{10}$ Wprowadzone m.in. ustawą z 13.10 .1998 r. - Przepisy wprowadzające ustawy reformujące administrację publiczną (Dz.U. Nr 133, poz. 872 ze zm.). 
W przeciwieństwie do zapisów Konstytucji RP z 17.03.1921 r. ${ }^{11}$ (której art. 66 zd. 2 stanowił, że „organy administracji państwowej w poszczególnych jednostkach terytorialnych mają być przy tym zespolone w jednym urzędzie pod jednym zwierzchnikiem") konstrukcja zespolenia administracyjnego nie została wyartykułowana w Konstytucji RP. Stała się natomiast jednym z fundamentów reformy administracyjnej, przeprowadzonej w 1998 r., w pewnym stopniu nawiązującej do tradycji II RP. Efektem nowo uporządkowanego systemu terytorialnego było m.in. powołanie do życia nieistniejącej dotąd w III RP kategorii jednostki samorządu terytorialnego, a mianowicie powiatu ${ }^{12}$.

Podstawowym założeniem nowo konstruowanego wówczas modelu ustroju państwa było uczynienie osią działania administracji publicznej układu terytorialnego i odejście od dotychczasowego układu branżowego, w którym kompetencje administracyjne zostały skoncentrowane na szczeblu centralnym ${ }^{13}$.

To implikowało konieczność zbudowania takiego modelu ustrojowego, w którym odpowiedzialność za wykonywanie podstawowych funkcji państwa na określonym terytorium spoczywać będzie na oznaczonym jednoosobowym organie. Zatem organ ten należało wyposażyć w odpowiednie ku temu kompetencje, składające się na konkretną postać władztwa publicznego. Powyższe zamierzenie twórców reformy znalazło swój wyraz w koncepcji władzy ogólnej, stanowiącej jedną z wiodących zasad ustroju zreformowanej w 1998 r. administracji publicznej, która polegała na tym, że odpowiedzialność za rezultat działania całej administracji określonego stopnia podziału terytorialnego, w tym również służb, in-

11 Dz.U. poz. 267 ze zm.

12 M. Mączyński, Starosta a powiatowa administracja zespolona w II i III Rzeczypospolitej (w okresie międzywojennym i wspótcześnie) [w:] Dziesięć lat reformy ustrojowej administracji publicznej w Polsce, red. J. Parchomiuk, B. Ulijasz, E. Kruk, Warszawa 2009, s. 164-165.

${ }_{13}$ M. Stec, Służby, inspekcje i straże $w$ nowym ustroju administracji publicznej, ST 1998/12, s. 19. 
spekcji i straży, ponosi jeden organ. Uosobieniem tego władztwa na obszarze województwa miał być wojewoda, natomiast w powiecie - starosta ${ }^{14}$.

W konsekwencji - jak podkreśla M. Stec, jeden z czołowych konsultantów reformy - to właśnie ten organ ponosić miał odpowiedzialność o charakterze politycznym za skutki działań własnych służb (inspekcji i straży), nad którymi sprawuje zwierzchnictwo, a nie tylko za dołożenie należytej staranności, czyli właściwe wykonywanie swoich obowiązków ${ }^{15}$.

Podsumowując powyższe wywody, stwierdzić należy, że zgodnie z zamysłem twórców reformy ustrojowej konstrukcja zespolenia administracji pozostawać miała w ścisłym powiązaniu ze zwierzchnictwem jednego organu nad innymi oraz z pojęciem władzy administracji ogólnej.

Zdaniem M. Steca zasadniczym kluczem do zrozumienia konstrukcji zwierzchnictwa i pojęcia władzy administracji ogólnej jest właśnie zasada zespolenia, która dla służb, inspekcji i straży stanowi najistotniejsze zagadnienie ${ }^{16}$.

W raporcie końcowym, opracowanym w ramach Programu Reformy Administracji Publicznej Instytutu Spraw Publicznych pt. Model ustrojowy województwa (regionu) w unitarnym państwie demokratycznym ${ }^{17}$, postulowano, że: „Policje administracyjne powinny zostać zespolone z organem administracji ogólnej szczebla wojewódzkiego (wojewoda) i lokalnego (organ wykonawczy samorządu). Problem jednolitości wykonywania władzy w państwie unitarnym może być zapewniony przez odpowiednio autoryzowanego urzędnika (dla określonej inspekcji), będącego osobą publicznego zaufania, który zapewni ochronę interesów państwa, samorządu lokalnego i obywateli. Tak więc administracja specjalna [...] stałaby się administracją zespoloną (działanie pod jednym zwierzchnikiem) [...]. Główny inspektor danej inspekcji byłby centralnym orga-

${ }^{14}$ E. Knosala, Zarys nauki administracji, Kraków 2005, s. 134.

15 E. Knosala, Zarys..., s. 116.

16 M. Stec, Służby..., s. 22.

17 Z. Gilowska, J. Płoskonka, S. Prutis, E. Wysocka, Model ustrojowy województwa (regionu) w unitarnym państwie demokratycznym, ST 1997/8-9, s. 132 i n. 
nem administracji państwowej. [...] Zgodnie z zamysłem autorów ww. projektu, wojewoda będzie odpowiadał za stan bezpieczeństwa związany $\mathrm{z}$ daną inspekcją na terenie województwa oraz koordynował działania w całym województwie w wypadku zagrożenia bezpieczeństwa w zakresie danej inspekcji. Będzie zapewniał warunki jej działania poprzez zespolenie organizacyjne [...] oraz upoważniał szefa wojewódzkiego inspektoratu. Takie same kompetencje powinien posiadać organ wykonawczy samorządu powiatowego na swoim obszarze terytorialnym [...]”.

Główne założenie reformy zostało implementowane, choć nie wprost, do ustawy o samorządzie powiatowym, poprzez powierzenie staroście władzy administracji ogólnej w powiecie. Choć w ustawie o samorządzie powiatowym starosta nie został wskazany jako organ powiatu, to w literaturze przedmiotu zostało przesądzone, że własne, wyodrębnione ustawowo zadania i kompetencje starosty czynią $\mathrm{z}$ niego $\mathrm{w}$ istocie odrębny organ wykonawczy w powiecie ${ }^{18}$.

I tak w wyniku reformy ustrojowej administracji publicznej część dotychczasowych organów administracji specjalnej została zespolona na szczeblu powiatowym ze starostą jako organem administracji ogólnej.

\section{Zespolenie administracji na przykładzie służb, inspekcji i straży}

Według art. 33b u.s.p. na powiatową zespoloną administrację terenową składają się:

- struktury samorządowe: starostwo powiatowe i powiatowy urząd pracy;

- struktury administracji rządowej, którymi są jednostki organizacyjne, stanowiące aparat pomocniczy kierowników powiatowych służb, inspekcji i straży.

${ }_{18}$ Z. Niewiadomski, Ustrój samorządu terytorialnego i administracji rządowej po reformie. Zbiór aktów prawnych z wprowadzeniem i objaśnieniami, Warszawa 1998, s. 20, 34, 41; J. Maćkowiak (doradca prawny w Departamencie Prawnym NIK), Ustrój powiatów i województw (zagadnienia wstępne), opinia wewnętrzna, s. 9-10. 
Niniejsze opracowanie poświęcone zostało rządowemu segmentowi powiatowej administracji zespolonej, który obejmuje jednostki organizacyjne stanowiące aparat pomocniczy kierowników powiatowych służb inspekcji i straży.

W obecnym stanie prawnym pod zwierzchnictwem starosty działa czterech kierowników powiatowych służb, inspekcji i straży. Kierownicy ci mają status organów administracji rządowej terenowej, posiadających własne zadania i kompetencje wykonywane za pomocą własnych aparatów pomocniczych ${ }^{19}$. Aparatami pomocniczymi organów w powiatowej administracji zespolonej obecnie są: Powiatowa Komenda Policji, Powiatowa Komenda Państwowej Straży Pożarnej, Powiatowy Inspektorat Nadzoru Budowlanego oraz Powiatowy Inspektorat Sanitarny.

W literaturze przedmiotu podkreśla się, że cechą charakterystyczną służb inspekcji i straży na szczeblu powiatu jest pozostawanie w relacji podwójnego podporządkowania; podlegają one bowiem zwierzchnictwu zarazem władz rządowych, jak i samorządowych. Zgodnie bowiem $z$ art. 4 ust. 2 u.s.p. zadania powiatu odnośnie do powiatowych służb, inspekcji i straży zostały zredukowane do obowiązku zapewnienia tym jednostkom wykonywania ich zadań i kompetencji. Zadania wykonywane przez powiatowe służby, inspekcje i straże nie są zadaniami powiatu (ani starosty), ale zadaniami tych służb, zwłaszcza ich kierowników, jako organów administracji rządowej ${ }^{20}$.

I tak z jednej strony podlegają zwierzchnictwu starosty (sensu largo), który wytycza ogólne kierunki działania zespolonych organów, koordynuje ich działalność, nie dysponując jednak prawem wydawania decyzji administracyjnych w zakresie ich działania; a z drugiej strony wojewódzkiego inspektora lub komendanta (sensu stricto), tj. przełożonego służbowego, kierującego działalnością zespolonego organu i wydającego decyzje administracyjne w zakresie jego działania.

19 Por. M. Chlipała [w:] Konstytucyjny..., red. P. Chmielnicki, s. 163 i n.

${ }^{20}$ J. Jagoda, Powiatowa (miejska) administracja zespolona [w:] Dziesięć...., red. J. Parchomiuk, B. Ulijasz, E. Kruk, s. 236. 
„Konsekwencją podwójnego podporządkowania jest zróżnicowany status prawny powiatowych służb, inspekcji i straży: z jednej strony stanowią stationes fisci administracji rządowej pod względem organizacyjno-ustrojowym, a z drugiej strony są powiatowymi jednostkami budżetowymi, podlegając zwierzchnictwu starosty"21.

Słuszny jest pogląd S. Czarnowa, że wadą obecnego unormowania jest brak przepisów konstytucyjnych w sprawie zespolenia administracji publicznej i w sprawie współpracy administracji rządowej z samorządową. W szczególności Konstytucja RP nie dopuszcza istnienia mieszanych organów rządowo-samorządowych ${ }^{22}$. W podsumowaniu swoich wywodów autor ten doszedł do konkluzji, że zespolenie administracji rządowej pod zwierzchnictwem samorządu terytorialnego musi mieścić się w ramach decentralizacji i nie może przerodzić się $\mathrm{w}$ autonomię ${ }^{23}$. Uprawnienia samorządu terytorialnego w stosunku do administracji zespolonej, wykonującej zadania rządowe, nie mogą być większe niż właściwych organów państwowych i nie mogą kolidować $\mathrm{z}$ rządowym charakterem zespolonych jednostek ${ }^{24}$.

\section{Wymiar zasady zespolenia odnośnie do powiatowych służb, inspekcji i straży}

Odpowiedzi na pytanie, czy i w jakim stopniu na gruncie obecnie obowiązujących przepisów prawnych zespolenie tych służb powiatowych stanowi kontynuację tworzenia systemu zgodnie z przyświecającą twórcom reform z 1998 r. koncepcją zespolenia w administracji, można udzielić po przeanalizowaniu aktualnych unormowań w kontekście poszczególnych jej aspektów.

${ }^{21}$ S. Czarnow, Zespolenie administracji na przykładzie służb, inspekcji i straży powiatowych, „Rejent” 2003/5 (145), s. 46-47.

22 S. Czarnow, Zespolenie..., s. 47.

23 S. Czarnow, Zespolenie..., s. 50.

${ }^{24} \mathrm{Cz}$. Martysz, Podział zadań i kompetencji pomiędzy jednostkami samorządu terytorialnego ze szczególnym uwzględnieniem samorządu powiatu i samorządu województwa [w:] Prawo administracyjne w okresie transformacji ustrojowej, red. E. Knosala, A. Matan, G. Łaszczyca, Warszawa 1999, s. 224 i n. 
W rozwiązaniach prawnych dotyczących organizacji powiatowej administracji zespolonej trudno doszukać się przejawów zespolenia organizacyjnego. Aparaty pomocnicze powiatowych służb inspekcji i straży, przy pomocy których kierownicy służb wykonują swoje kompetencje, ulokowane zostały poza strukturą organizacyjną starostwa powiatowego. Ponadto każda z jednostek tworzących administrację zespolą w powiecie działa na podstawie własnego statutu i regulaminu organizacyjnego, które nie podlegają zatwierdzeniu przez starostę.

W mojej ocenie za pewien refleks zespolenia organizacyjnego można uznać przyznanie staroście uprawnień o charakterze inicjującym, związanym z wystąpieniem do wojewody z wnioskiem o utworzenie, przekształcenie lub likwidację jednostek organizacyjnych, stanowiących aparat pomocniczy kierowników powiatowych służb inspekcji i straży. Wniosek ten podlega zaopiniowaniu przez właściwego kierownika zespolonej służby, inspekcji i straży wojewódzkiej ${ }^{25}$. Przepisy szczególne mogą wyłączać tę procedurę, i tak dla przykładu art. 8a ust. 1 ustawy z 6.04.1990 r. o Policji ${ }^{26}$ stanowi, że tworzenie rewirów dzielnicowych oraz posterunków policji należy do komendanta powiatowego (miejskiego) policji na zasadach określonych przez Komendanta Głównego Policji.

Przepis art. 33a ust. 3 u.s.p. stanowi o realizacji aspektu finansowego zasady zespolenia, będącego w zasadzie pochodną kwestii organizacyjnej, dotyczy bowiem włączenia budżetu danej służby czy inspekcji (z wyjątkiem Policji) do budżetu powiatu. W nawiązaniu do tego przepisu art. 8 ust. 2 ustawy z 13.11.2003 r. o dochodach jednostek samorządu terytorialnego ${ }^{27}$ wśród dochodów powiatu wymienia dotacje celowe $\mathrm{z}$ budżetu państwa na realizację zadań straży i inspekcji, o których mowa w ustawie o samorządzie powiatowym. Pamiętać przy tym należy, że więź oparta na zasadzie zespolenia finansowego traktowana jest w nauce prawa administracyjnego jako słabsza, mniej istotna postać zespolenia.

\footnotetext{
25 Art. 33a ust. 2 u.s.p.

26 Dz.U. z 2017 r. poz. 2067 ze zm.

27 Dz.U. z 2018 r. poz. 1530 ze zm.
} 
Przechodząc następnie do analizy kluczowego, z punktu widzenia konstrukcji zasady zespolenia, aspektu osobowego, wspomnieć należy w tym miejscu, że warunkiem jego realizacji jest przyznanie staroście stanowczego wpływu na obsadę personalną poszczególnych kierowników zespolonych służb. Z art. 35 ust. 3 pkt 1 u.s.p. wynika m.in., że starosta powołuje kierowników powiatowych służb inspekcji i straży, w uzgodnieniu z wojewodą, jeżeli przepisy szczególne nie stanowią inaczej.

Z art. 86 ust. 1 ustawy z 7.07.1994 r. - Prawo budowlane ${ }^{28}$, regulującego tryb powoływania powiatowego inspektora nadzoru budowlanego, wynika, że starosta ma możliwość wyboru osoby na to stanowisko spośród trzech kandydatów wskazanych przez wojewódzkiego inspektora nadzoru budowlanego. Ponadto, jeżeli starosta w terminie 30 dni żadnego z nich nie powoła na stanowisko, o którym mowa, wojewódzki inspektor nadzoru budowlanego wskaże, którego kandydata starosta ma obowiązek powołać do pełnienia funkcji powiatowego inspektora nadzoru budowlanego.

Stosownie do art. 86 ust. 2 ww. ustawy odwołania powiatowego inspektora nadzoru budowlanego starosta dokonuje w uzgodnieniu z wojewódzkim inspektorem nadzoru budowlanego albo na wniosek wojewódzkiego inspektora nadzoru budowlanego.

Zatem również odwołanie $\mathrm{z}$ tego stanowiska nie jest samodzielnym uprawieniem starosty ${ }^{29}$. To do wojewódzkiego inspektora należeć będzie wybór spośród kandydatów, którzy - jego zdaniem - będą spełniać wymogi pozwalające na sprawowanie przez nich kierowniczej funkcji.

O samodzielności starosty też nie może być mowy w przypadku powoływania i odwoływania państwowego powiatowego inspektora sanitarnego. Zgodnie bowiem z art. 11 ust. 3 ustawy z 14.03.1985 r.

${ }^{28}$ Dz.U. z 2018 r. poz. 1202 ze zm.

29 R. Dziwiński, P. Ziemski, Prawo budowlane. Komentarz, Warszawa 2006; C. Kociński, Współdziałanie organów przy odwołaniu powiatowego inspektora nadzoru budowlanego, „Nowe Zeszyty Samorządowe” 2002/5, s. 47. 
o Państwowej Inspekcji Sanitarnej ${ }^{30}$ do dokonania tej czynności starosta musi posiadać zgodę państwowego wojewódzkiego inspektora sanitarnego ${ }^{31}$. Jeszcze większego osłabienia wymienione uprawnienie starosty doznało na gruncie wspomnianej ustawy o Policji i ustawy o Państwowej Straży Pożarnej32. Komendanta powiatowego (miejskiego) Policji powołuje komendant wojewódzki, po zasięgnięciu opinii starosty. Podnieść w tym miejscu należy, że wspomniana opinia starosty nie ma charakteru wiążącego. Komendant wojewódzki ma obowiązek wystąpić o nią, ale nie musi postąpić zgodnie z jej treścią. Ponadto w przypadku nieotrzymania opinii, o której mowa, komendant wojewódzki może powołać komendanta powiatowego po upływie 14 dni od dnia przedstawienia wniosku o wydanie opinii. Analogicznie przedstawia się procedura odwołania komendanta.

Z kolei komendanta powiatowego (miejskiego) Państwowej Straży Pożarnej powołuje spośród oficerów Państwowej Straży Pożarnej komendant wojewódzki Państwowej Straży Pożarnej w porozumieniu ze starostą.

W razie niezajęcia stanowiska lub niezaakceptowania zgłoszonej kandydatury na stanowisko komendanta powiatowego (miejskiego) Państwowej Straży Pożarnej w terminie 30 dni od dnia jej przedstawienia staroście przedstawia się niezwłocznie kolejną kandydaturę. W przypadku braku porozumienia w stosunku do tej kandydatury w terminie 14 dni od dnia jej przedstawienia staroście na stanowisko komendanta powiatowego (miejskiego) Państwowej Straży Pożarnej komendant wojewódzki Państwowej Straży Pożarnej powołuje wskazanego przez wojewodę oficera Państwowej Straży Pożarnej.

Analiza przepisów ustaw szczególnych dotyczących służb inspekcji i straży, w szczególności ustawy o Policji i ustawy o Państwowej Straży Pożarnej, prowadzi do wniosku, że w znacznym stopniu ograniczają

${ }^{30}$ Dz.U. z 2017 r. poz. 1261 ze zm.

31 A. Wierzbicka [w:] Administracja publiczna. Ustrój administracji samorządowej. Komentarz, red. B. Szmulik, K. Miaskowska-Daszkiewicz, Warszawa 2012, s. 389.

${ }^{32}$ Dz.U. z 2018 r. poz. 1313 ze zm. 
one, żeby nie pokusić się o stwierdzenie „przejmują”, kompetencje starosty wynikające z ustawy o samorządzie powiatowym w zakresie dotyczącym personalnej obsady kierowniczych stanowisk. Unormowania zawarte w ustawie o Policji i ustawie o Państwowej Straży Pożarnej wprost wyłączają zastosowanie przepisu art. 35 ust. 3 pkt 1 u.s.p.

W pewnym uogólnieniu można zatem stwierdzić, że przepisy ustaw szczególnych kreują sytuację, w której to do wojewódzkiego inspektora/komendanta należeć będzie wybór wyżej wymienionych kandydatów spełniających jego zdaniem wymogi pozwalające na sprawowanie przez nich kierowniczej funkcji.

Można zatem wysnuć uzasadnioną tezę, że zdecydowany wpływ na obsadę kierowniczych stanowisk w zespolonej administracji rządowej na szczeblu powiatu ma władza centralna (administracja rządowa), której ogniwem jest wojewoda, działający w zespoleniu z wojewódzkimi inspektorami/komendantami.

Podsumowując powyższe wywody, zestawiając treść przepisu art. 35 ust. 3 w zw. z art. 33a u.s.p. z przepisami ustaw szczególnych dotyczących służb inspekcji i straży, należy stwierdzić, że starosta ma znikomy wpływ na obsadę stanowisk powiatowych komendantów i inspektorów. Przepis art. 33a u.s.p. stanowi, iż szczególne warunki lub zasady powoływania, odwoływania oraz tryb zatrudniania i zwalniania kierowników i pracowników powiatowych służb, inspekcji i straży określają odrębne przepisy. W świetle tego unormowania przepis art. 35 ust. 3 pkt 1 u.s.p., z którego wynika, że starosta powołuje kierowników powiatowych służb inspekcji i straży, w uzgodnieniu z wojewodą, jeżeli przepisy szczególne nie stanowią inaczej, wydaje się zbędny i komplikuje dodatkowo i tak mało przejrzystą regulację dotyczącą powiatowej administracji zespolonej.

Nasuwa się w tym miejscu refleksja, w jakim celu w ogóle umieszczono ten przepis. Wydaje się, że służy on jedynie dalszemu podtrzymaniu wrażenia, że podstawowy element zwierzchnictwa starosty w stosunku do powiatowych służb inspekcji i straży, przejawiający się w zespoleniu osobowym, w dalszym ciągu występuje. 
Przechodząc następnie do kluczowego dla zasady zespolenia - jej kompetencyjnego aspektu - podkreślenia wymaga to, że kierownicy powiatowych służb zawsze działają w imieniu własnym i nie ma prawnych możliwości przejęcia ich kompetencji przez starostę. Zespolenie kompetencyjne nie występuje w zespolonej administracji powiatowej w ogóle. O ile zatem starosta ponosi odpowiedzialność w sensie politycznym za skutki działań tych organów, o tyle w zakresie postępowania administracyjnego organy te odpowiadają wyłącznie wobec odpowiednich organów wyższego stopnia ${ }^{33}$.

Podsumowując, stwierdzić należy, że organy służb, inspekcji i straży pomimo ich formalnego zespolenia ze starostą pozostają organami administracji rządowej, a wykonując zadania powiatu, czynią to we własnym imieniu i mają do pomocy własny aparat pomocniczy, co wynika wprost z art. 33a u.s.p. Wyjątkiem od tej zasady są sytuacje, w których organy te będą działać na podstawie udzielonego im upoważnienia do wydawania decyzji w imieniu starosty i na jego odpowiedzialność, $\mathrm{w}$ trybie przewidzianym w art. 38 ust. 2 u.s.p. (tzw. pełnomocnictwo administracyjne). Należy przy tym podkreślić, że starosta może upoważnić tylko w zakresie tych kompetencji, które mu przysługują ${ }^{34}$. Wówczas powiatowy inspektor będzie realizował zadania powiatu za starostę jako podmiot wykonujący funkcje organu administracji publicznej w ramach dekoncentracji wewnętrznej, a więc będzie stanowić aparat pomocniczy starosty ${ }^{35}$. Konstatując, powierzenie inspektorowi na zasadzie art. 38 ust. 2 u.s.p. wydawania decyzji administracyjnych w imieniu starosty nie jest w żadnej mierze przejawem zespolenia kompetencyjnego, ale stanowi przykład dekoncentracji wewnętrznej. Powyższa analiza wskazuje, że w rzeczywistości żaden aspekt omawianej zasady, poza finansowym (który nie dotyczy Policji), nie występuje wobec wspomnianych służb powiatowych. Mając na uwadze to, że w nauce prawa administracyjnego za konstytutywne cechy składające się na konstrukcję zespolenia apa-

${ }^{33}$ Ustawa o samorzadzie powiatowym. Komentarz, red. B. Dolnicki, Warszawa 2007, s. 299-300.

${ }^{34}$ Por. K. Bandarzewski [w:] K. Bandarzewski [et al.], Komentarz do ustawy o samorzqdzie powiatowym, red. P. Chmielnicki, Warszawa 2005, s. 268-269.

${ }_{35}$ Zob. Cz. Martysz [w:] Ustawa..., red. B. Dolnicki, s. 300. 
ratu administracyjnego uznaje się aspekt osobowy i kompetencyjny, słuszna wydaje się teza, iż podstawa normatywna zespolenia powiatowych służb i straży ma iluzoryczny wymiar. Słuszne wobec tego wydaje się pytanie M. Smagi, czy zespolenie obejmujące powiatowe służby, inspekcje i straże nie jest instytucją semantycznie pustą, która w praktyce nie istnieje ${ }^{36}$.

W obecnym stanie prawnym zyskuje na aktualności pogląd M. Mączyńskiego, że zespolenie obejmujące służby i straże powiatowe jest przede wszystkim wyrazem zwierzchnictwa starosty nad nimi i obejmuje jedynie uprawnienia określone w ustawie o samorządzie powiatowym i ustawach działowych ${ }^{37}$.

Zwierzchnictwo starosty w stosunku do powiatowych służb, inspekcji i straży, wynikające $z$ art. 35 ust. 2 i ust. 3 u.s.p., poza pozornym decydowaniem o obsadzie kierowniczych stanowisk wymienionych służb, sprowadza się do zatwierdzenia programów ich działania, uzgadniania wspólnego działania tych jednostek na obszarze powiatu, w sytuacjach szczególnych - kierowania wspólnymi działaniami tych jednostek oraz zlecania w uzasadnionych przypadkach przeprowadzenia kontroli.

Jednakże, co już było wyżej podnoszone, wynikające z tytułu sprawowania przez starostę zwierzchnictwa nad inspekcjami, służbami i strażami, skonkretyzowane w art. 35 ust. 3 pkt 1 u.s.p., uprawnienia nie mają jednak zastosowania do unormowań zawartych w ustawie o Policji i ustawie o Państwowej Straży Pożarnej, z których wprost wyłączono zasadę zwierzchnictwa starosty nad tymi służbami.

Ponadto zaprezentowany w ustawie o samorządzie powiatowym kształt zwierzchnictwa starosty wobec służb powiatowych daleki jest od prezentowanego w literaturze przedmiotu modelu zwierzchnictwa.

${ }^{36}$ Por. M. Smaga, Administracja publiczna w czasie klęski żywiołowej, Kraków 2004, s. 80.

${ }^{37}$ M. Mączyński, Powiat w systemie ochrony bezpieczeństwa i porządku publicznego, „Przegląd Prawa Publicznego” 2007/6, s. 82. 
Ze stanowiska teoretycznoprawnego przyjąć należy, że konstrukcja zwierzchnictwa występuje wtedy, gdy określona władza administracyjna (w tym przypadku starosta) ma uprawnienia kierownicze wobec innych, wyspecjalizowanych organów administracji publicznej. Łączy się to z założeniem, że taka władza administracyjna odpowiada za stan spraw publicznych, na który składają się rezultaty działania, na danym terenie również innych organów administracji publicznej, mających własne, przypisane im ustawami zdania i kompetencje. Jest to więc swoista odpowiedzialność za skutek.

Jak wynika z przepisu art. 35 u.s.p., starosta nie sprawuje kierownictwa ani bezpośredniego zwierzchnictwa służbowego nad powiatowymi służbami, inspekcjami czy strażami, ma tylko określony wpływ na ich działalność, wyrażający się głównie przez udzielanie im wytycznych i wskazywaniu problemów do rozwiązania. Wymienione kompetencje mają więc w istocie charakter konsultacyjno-koordynacyjno-kontrolny ${ }^{38}$. Ponadto kierownicy powiatowych służb zawsze działają w imieniu własnym i nie ma prawnych możliwości przejęcia ich kompetencji przez starostę.

Zwierzchnictwo starosty nad służbami powiatowymi przejawią się również, poza wyżej omówionymi kompetencjami zawartymi w ustawie o samorządzie powiatowym (art. 35 ust. 3), w ustawach działowych. Najważniejsza z nich polega na przyznaniu staroście w przypadku szczególnego zagrożenia bezpieczeństwa (art. 14 ustawy o Państwowej Straży Pożarnej, art. 89c Prawa budowlanego), w szczególności zaś zagrożenia życia lub zdrowia ludzi, prawa do wydawania odpowiedniemu inspektorowi lub komendantowi powiatowemu polecenia podjęcia działań mających na celu usunięcie tego zagrożenia. Polecenie to nie może jednak dotyczyć wykonania konkretnych czynności służbowych ani określać sposobu wykonania zadania. Konsekwencją tego uprawnienia, stanowiącego przejaw zwierzchnictwa, jest zawarte wyraźnie w przepisach prawa stwierdzenie o ponoszeniu odpowiedzialności przez starostę za treść i skutki tych poleceń, czyli odpowiedzialności o charakterze politycznym. W zbliżony

${ }^{38}$ W. Kisiel, Ustrój samorządu terytorialnego w Polsce, Warszawa 2003, s. 203 i 204. 
sposób uprawnienie to sformułowane jest w art. 11 ustawy o Policji, zgodnie z którym staroście przysługuje prawo żądania od powiatowego komendanta policji przywrócenia stanu zgodnego z porządkiem prawnym lub podjęcia działań zapobiegających naruszeniu, a także zmierzających do usunięcia zagrożenia bezpieczeństwa i porządku publicznego, przy czym żądanie to nie może dotyczyć czynności operacyjno-rozpoznawczych, dochodzeniowo-śledczych oraz czynności z zakresu ścigania wykroczeń, a także wykonywania konkretnej czynności służbowej, ani określać sposobu wykonywania zadania. I podobnie, jak w przypadku innych służb, za treść żądania wyłączną odpowiedzialność ponosi starosta.

W literaturze przedmiotu coraz częściej podkreśla się, że mimo pierwotnej tendencji do powierzenia staroście w ramach idei zespolenia kompetencji zwierzchnich w zakresie wykonywania i koordynowania zadań o charakterze rządowym, w sferach działań istotnych z punktu widzenia polityki państwa i jednoczesnego podkreślania istoty roli starosty we wskazanym aspekcie, mamy do czynienia z postępującym ograniczaniem zakresu i realnej mocy sprawczej jego uprawnień oraz zasadniczej przewagi hierarchicznej struktury kierownictwa organizacyjnego z udziałem wojewody w poszczególnych postaciach zwierzchnictwa nad powiatowymi służbami, inspekcjami i strażami ${ }^{39}$.

W konstatacji powyższych rozważań wskazać należy, że warunkiem realności konstrukcji zwierzchnictwa starosty w stosunku do powiatowych służb, inspekcji i straży jest przypisanie temu organowi uprawnień zwierzchnich względem zespolonej administracji specjalnej. Starosta nie ma takich kompetencji względem administracji terenowej, żeby można było mu przypisać odpowiedzialność za zadania zespolonych z nimi organów. Z obecnego kształtu ustaw regulujących status służb, inspekcji czy straży na szczeblu powiatowym wyraźnie przebijają tendencje zmierzające do wzmocnienia wpływów centrali-

39 J. Sługocki, Prawo administracyjne. Zagadnienia ustrojowe, Warszawa 2012, s. 330-331; J. Zimmermann, Prawo administracyjne, Warszawa 2010, s. 212; K. Lewandowski, E. Wituska, Dychotomia starosty powiatowego w strukturze terenowej administracji publicznej, „Studia z Zakresu Prawa, Administracji i Zarządzania UKW” 2012/2, s. 44. 
stycznych na działalność organów terenowych kosztem stopniowego umniejszania znaczenia przedstawiciela władzy samorządowej - starosty. Jak bowiem widać z powyższej analizy, kompetencje starosty względem organów administracji rządowej terenowej zostały znacząco uszczuplone na rzecz organów władzy centralnej, która stopniowo zyskuje w terenie realne wpływy. Już bowiem na podstawie powyższego opracowania można zauważyć występujące na analizowanym obszarze zjawisko recentralizacji zadań powiatowych ${ }^{40}$.

\section{Bibliografia:}

Administracja publiczna. Ustrój administracji samorządowej. Komentarz, red. B. Szmulik, K. Miaskowska-Daszkiewicz, Warszawa 2012

Baraniecki Cz., Konicki J., Konstrukcja zespolenia w polskiej administracji publicznej, „Ius et Administratio” 2006/10(2)

Cieślak S., Zasady organizowania administracji publicznej, Przemyśl 2014

Dolnicki B., Powiat - dziesięć lat funkcjonowania [w:] Dziesięć lat reformy ustrojowej administracji publicznej w Polsce, red. J. Parchomiuk, B. Ulijasz, E. Kruk, Warszawa 2009

Dziuban E., Realizacja zasady zespolenia $w$ administracji rządowej w województwie, „Przegląd Prawa Publicznego” 2014/9

Dziwiński R., Ziemski P., Prawo budowlane. Komentarz, Warszawa 2006

Gilowska Z., Płoskonka J., Prutis S., Wysocka E., Model ustrojowy województwa (regionu) w unitarnym państwie demokratycznym, ST 1997/8-9

Jagoda J., Powiatowa (miejska) administracja zespolona [w:] Dziesięć lat reformy ustrojowej administracji publicznej w Polsce, red. J. Parchomiuk, B. Ulijasz, E. Kruk, Warszawa 2009

Jaskiernia J., Zasady organizacji administracji rzadowej [w:] Konstytucyjny system władz publicznych, red. P. Chmielnicki, Warszawa 2009

Knosala E., Zarys nauki administracji, Kraków 2005

Kociński C., Współdziałanie organów przy odwołaniu powiatowego inspektora nadzoru budowlanego, „Nowe Zeszyty Samorządowe” 2002/5

Konstytucyjny system władz publicznych, red. P. Chmielnicki, Warszawa 2009

${ }^{40}$ B. Dolnicki, Powiat - dziesięć lat funkcjonowania [w:] Dziesięć..., red. J. Parchomiuk, B. Ulijasz, E. Kruk, s. 107. 
Leoński Z., Zarys prawa administracyjnego, Warszawa 2004

Lewandowski K., Wituska E., Dychotomia starosty powiatowego w strukturze terenowej administracji publicznej, „Studia z Zakresu Prawa, Administracji i Zarządzania UKW" 2012/2

Maćkowiak J., Ustrój powiatów i województw (zagadnienia wstępne), opinia wewnętrzna

Martysz Cz., Podział zadań i kompetencji pomiędzy jednostkami samorządu terytorialnego ze szczególnym uwzględnieniem samorządu powiatu i samorzadu województwa [w:] Prawo administracyjne w okresie transformacji ustrojowej, red. E. Knosala, A. Matan, G. Łaszczyca, Warszawa 1999

Mączyński M., Powiat w systemie ochrony bezpieczeństwa i porządku publicznego, „Przegląd Prawa Publicznego” 2007/6

Mączyński M., Starosta a powiatowa administracja zespolona w II i III Rzeczypospolitej (w okresie międzywojennym i współcześnie) [w:] Dziesięć lat reformy ustrojowej administracji publicznej w Polsce, red. J. Parchomiuk, B. Ulijasz, E. Kruk, Warszawa 2009

Niewiadomski Z., Ustrój samorządu terytorialnego i administracji rządowej po reformie. Zbiór aktów prawnych z wprowadzeniem i objaśnieniami, Warszawa 1998

Sługocki J., Prawo administracyjne. Zagadnienia ustrojowe, Warszawa 2012

Smaga M., Administracja publiczna w czasie klęski żywiołowej, Kraków 2004

Starościak J., Prawo administracyjne, Warszawa 1996

Stec M., Służby, inspekcje i straże w nowym ustroju administracji publicznej, ST $1998 / 12$

Szreniawski J., Wstęp do nauki administracji, Lublin 2000

Tusiński P., Zasady ustrojowego prawa administracyjnego [w:] Ustrojowe prawo administracyjne, red. L. Bielecki, P. Ruczkowski, Warszawa 2011

Ustawa o samorzadzie powiatowym. Komentarz, red. B. Dolnicki, Warszawa 2007 Wiktorowska A., Terenowe organy administracji państwowej [w:] System Prawa Administracyjnego, t. 6, Podmioty administrujące, red. R. Hauser, Z. Niewiadomski, A. Wróbel, Warszawa 2011

Zimmermann J., Prawo administracyjne, Warszawa 2010 